\title{
The spread of Reynoutria species (Polygonaceae) in Kampinos National Park and its vicinity (Central Poland)
}

\author{
IZABELLA KIRPLUK \\ ANNA BOMANOWSKA \\ ANNA OTRĘBA
}

KIRPLUK I., BOMANOWSKA A., OTRĘBA A. (2019). The spread of Reynoutria species (Polygonaceae) in Kampinos National Park and its vicinity (Central Poland). Chornomors 'k. bot. z., 15 (1): 17-25. doi: 10.32999/ksu1990-553X/2019-15-1-2

Knotweed taxa: Reynoutria japonica, $R$. sachalinensis and $R$. × bohemica have been classified as the most dangerous invasive plants in Europe, North America, and other regions with cool climates. In Poland they are included on the list of 16 alien plant species which, when introduced into the natural environment, pose a threat to native biodiversity or natural habitats. Despite the serious threat they pose, Reynoutria species are still grown as ornamental plants, and are sometimes planted in hedges. Studies aimed at the identification of the range and the method of spread of knotweeds in settlement areas in Kampinos National Park and its vicinity were carried out from 2012. In mid-2018 there were 176 known sites where different species of Reynoutria were found. Most of these sites (118) were formed by $R$. japonica. $R$. × bohemica was found on 54 sites, and $R$. sachalinensis only on four sites. Home gardens are a source of Reynoutria species spread in the region of Kampinoska Forest (national park with its buffer zone). Our results showed that the most of the Reynoutria species sites were located within the administrative borders of investigated localities, at different distances from home gardens, where these plants are grown. Although the distribution of knotweeds is largely limited to ruderal habitats, these invasive plants, especially $R$. japonica and $R$. $\times$ bohemica, create a threat to semi-natural and natural biocoenoses at Kampinos National Park. R. sachalinensis was found only in villages on the periphery of KNP. Giant knotweed usually occupies large areas and form dense, homogeneous populations. It is necessary to constantly monitor the existing sites of knotweeds and prevent the formation of new stands in the area of Kampinos National Park and its close vicinity.

Keywords: invasive plants, rural areas, synanthropic habitats, protected area

КІРПЛЮК І., БОМАНОВСЬКА А., ОТРЕБА А. (2019). Поширення видів Reynoutria (Polygonaceae) в Національному парку Кампінос і його околицях (Центральна Польща). Чорноморськ. бот. ж., 15 (1): 17-25. doi: 10.32999/ksu1990-553X/2019-15$1-2$

Таксони Reynoutria japonica, $R$. sachalinensis і $R$. × bohemica були класифіковані як найбільш небезпечні інвазивні рослини в Європі, Північній Америці та інших регіонах з прохолодним кліматом. У Польщі вони включені в список 16 чужорідних видів рослин, які при інтродукції в природне середовище створюють загрозу для біорізноманіття або природного місця існування. Незважаючи на серйозну загрозу, яку вони представляють, види Reynoutria все ще вирощуються як декоративні рослини, а іноді і висаджуються як живі огорожі. Дослідження, спрямовані на виявлення ареалу i способів поширення цих рослин в населених пунктах національного парку Кампінос і його околиць, проводилися з 2012 року. До середини 2018 року було встановлено 176 локалітетів, де були виявлені різні види Reynoutria. Більшість 3 цих місцезростань (118) були сформовані $R$. japonica. $R$. × bohemica був виявлений на 54 ділянках, а $R$. sachalinensis - тільки на чотирьох ділянках. Домашні сади є джерелом поширення видів Reynoutria в районі лісу Національного парку 
Кампінос (національний парк з його буферною зоною). Наші результати показали, що більшість видів Reynoutria були розташовані в адміністративних межах досліджених місцевостей, на різних відстанях від присадибних ділянок, де вирощуються ці рослини. Хоча поширення цих рослин в основному обмежена рудеральними угрупованнями, ці інвазивні рослини, особливо $R$. japonica i $R$. ×bohemica, створюють загрозу для напівнатуральних і природних біоценозів в національному парку Кампінос. $R$. sachalinensis був виявлений тільки в селах на периферії Національного парку Кампінос. Рослина зазвичай займає великі площі і утворює щільні, однорідні популяції. Необхідно постійно стежити за його існуючими локалітетами і не допускати утворення нових насаджень в районі Національного парку Кампінос і його безпосередній близькості.

Ключові слова: інвазивні рослини, сільські райони, синантропні місия існування, території, щзо охороняються

КИРПЛЮК И., БОМАНОВСКА А., ОТРЕБА А. (2019). Распространение видов Reynoutria (Polygonaceae) в Национальном парке Кампинос и его окрестностях (Центральная Польша). Черноморск. бот. ж., 15 (1): 17-25. doi: 10.32999/ksu1990$553 \mathrm{X} / 2019-15-1-2$

Таксоны Reynoutria japonica, $R$. sachalinensis и $R$. × bohemica были классифицированы как наиболее опасные инвазивные растения в Европе, Северной Америке и других регионах с прохладным климатом. В Польше они включены в список 16 чужеродных видов растений, которые при интродукции в естественную среду создают угрозу для биоразнообразия или естественной среды обитания. Несмотря на серьезную угрозу, которую они представляют, виды Reynoutria все еще выращиваются в качестве декоративных растений, а иногда и высаживаются на живых изгородях. Исследования, направленные на выявление ареала и способов распространения этих растений в населенных пунктах национального парка Кампинос и его окрестностей, проводились с 2012 года. До середины 2018 года было установлено 176 локалитетов, где были обнаружены различные виды Reynoutria. Большинство из этих метопроизростаний (118) были сформированы $R$. japonica. R. ×bohemica был обнаружен на 54 участках, а $R$. sachalinensis - только на четырёх участках. Домашние сады являются источником распространения видов Reynoutria в районе Кампиносского леса (национальный парк с его буферной зоной). Наши результаты показали, что большинство видов Reynoutria были расположены в административных границах исследованных местностей, на разных расстояниях от приусадебных участков, где выращиваются эти растения. Хотя распространение узловатых в основном ограничено рудеральными местами обитания, эти инвазивные растения, особенно $R$. japonica и $R$. × bohemica, создают угрозу для полунатуральных и естественных биоценозов в национальном парке Кампинос. R. sachalinensis был обнаружен только в селах на периферии Национального парка Кампинос. Растение обычно занимает большие площади и образует плотные, однородные популяции. Необходимо постоянно следить за его существующими локалитетами и не допускать образования новых насаждений в районе Национального парка Кампинос и его непосредственной близости.

Ключевые слова: инвазивные растения, сельские районы, синантропные места обитания, охраняемая территория

Kampinos National Park (KNP), established in 1959, the second largest national park in Poland (surface area - $385 \mathrm{~km}^{2}$, buffer zone - $378 \mathrm{~km}^{2}$ ), UNESCO MaB Reserve "Puszcza Kampinoska" (established in 2000) and Natura 2000 site "Puszcza Kampinoska" (established in 2004), have been for many years under strong anthropogenic pressure [ANDRZEJEWSKI, 2004]. This results from the Park's location in the temperate climate zone, the lack of geographical barriers, as well as urban pressure. KNP is situated in the Central Masovian Lowland, in the Warsaw Basin, near Warsaw, the largest metropolis in Poland. Strong urban pressure also results from the close neighbourhood of the town of Łomianki, as well as many villages that have functions, infrastructure and development typical of small towns. These 
factors have a huge impact on the spread of invasive species [OTRĘBA, 2008; BOMANOWSKA et al., 2014], including taxa from the genus Reynoutria [KIRPLUK, 2014].

Knotweed species: Reynoutria japonica Houtt., Reynoutria $\times$ bohemica Chrtek \& Chrtková and Reynoutria sachalinensis (F.Schmidt) Nakai are kenophytes, i.e. alien species permanently established in synanthropic habitats, also penetrating into semi-natural and natural plant communities. They are regarded as one of the most invasive species in the world [TOKARSKA-GUZIK et al., 2017; SHEVERA, 2017]. IUCN listed Reynoutria japonica among the 100 most invasive species [GISD 2010], and according to the DAISIE database (2006) this is one of the 18 most invasive plants in Europe. These three species are troublesome from an environmental and conservation point of view, as they are one of the most prevalent and destructive alien plants in the European protected areas [MONACO, GENOVESI, 2014; BRAUN et al., 2016].

Since the end of the 19th century, knotweeds gradually invaded increasingly larger areas in Europe. During the last decade, massive and rapid spread of these aggressive new aliens in Eastern and Southeastern Europe has been observed. Currently, these species are established in most of countries of the Carpathian Basin and Balkan Peninsula, e.g. Croatia, Bosnia and Herzegovina, Bulgaria, Hungary, Kosovo, Montenegro, Romania, Serbia and Slovenia [BAlogh, 2008; Sîrbu, OpreA, 2008; Sîrbu et al., 2012; Hlavati ŠIrkA et al.,2013; DUMITRAŞCU et al., 2014, JOVANOVIĆ et al., 2018]. At present knotweeds are rapidly expanding in Ukraine, mainly in Western part of country [PROTOPOPOVA et al. 2006]. According to Prots [2013] and Prototopova and SheVera [2014] $R$. japonica and $R$. $\times$ bohemica are the most harmful alien species for the Transcarpathia region. $R$. japonica is recognized as transformer species in Ukrainian Polissya [PROTOPOPOVA et al., 2015]. $R$. $\times$ bohemica is considered as a potentially invasive species. At present it has been found in several localities from western (Transcarpathia, Chernivtsi and Lviv regions) and central (Zhytomyr, Kyiv and Poltava regions) parts of Ukraine [SHEVERA, 2017]. Results of numerous studies and observations provide evidences that knotweeds could become widespread throughout Ukraine under the current trend of expansion. The tendency of expansion of these invasive species eastward, i.e. forest-steppe and steppe zones of Ukraine has been observed [BURDA et al., 2015; HOLOBORODKO et al., 2016; PASHKEVYCH, BURDA, 2017].

In Poland knotweed species $R$. japonica, $R$. sachalinensis and $R$. $\times$ bohemica are also regarded as dangerous species and have the highest (IV) category of invasiveness [TOKARSKA-GUZIK et al., 2012]. They are included on the list of 16 plant species which, when introduced into the natural environment, may pose a threat to native species or natural habitats [Dz. U. 2011 no. 210, item 1260].

The aim of the study was to identify sites of Reynoutria species in the area of Kampinos National Park and in its immediate vicinity, their distribution, methods of spread of these taxa to the plant communities of KNP, and factors promoting their invasion.

\section{Materials and methods}

A detailed floristic survey was carried out in 2012-2018 on the settlement areas in KNP and its direct vicinity, i.e. 33 villages within the limits of the national park and 102 villages in the buffer zone. Special emphasis was put on the identification of taxa that are often confused, i.e. $R$. japonica and $R$. × bohemica. To finally verify the number of sites of Reynoutria species we also analysed historical data, gathered by the authors of this paper and other researchers [OTRĘBA, MiCHALSKA-HEJDUK, 2014], including unpublished information. On the basis of these data a map of current locations of Reynoutria taxa was prepared in ArcGIS. 


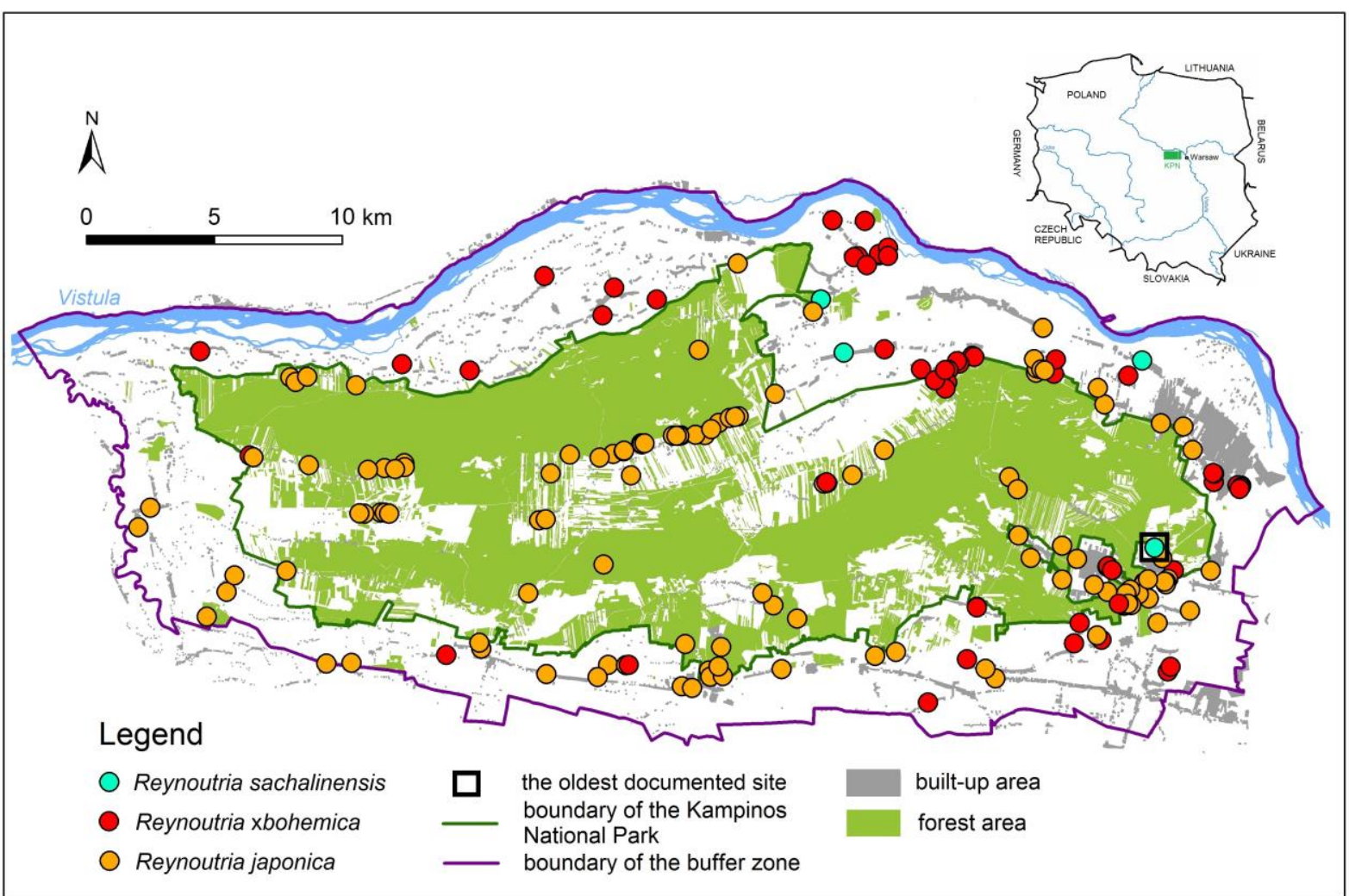

Fig. 1. Distribution of the Reynoutria species within the area of the Kampinos National Park (from 1985 to 2018).

Рис. 1. Поширення видів Reynoutria у Національному парку Кампніос (3 1985 по 2018 роки).

During the field survey we also monitored the existing, previously reported sites of knotweed species.

The nomenclature of taxa is consistent with "The International Plant Names Index" [The Plant LIST, 2013], and their synanthropic status with the classification proposed by Sudnik-Wójcikowska \& Koźniewska [SUDNIK-WÓJCIKOWSKA, KoŹNIEWSKA, 1988].

\section{Results}

In mid-2018 there were 176 known sites where different species of Reynoutria were found. Most of these sites were formed by $R$. japonica (118, of which 64 are within the national park and 54 in the buffer zone). R. × bohemica was found on 54 sites (six in the national park and 48 in the buffer zone), while $R$. sachalinensis - on four sites (all in the buffer zone) (Fig. 1).

Our observations revealed that most of the sites occupied by Reynoutria species were located within the administrative borders of smaller and larger villages, at different distances from home gardens, where these plants are grown. In 33 villages within the limits of Kampinos National Park we mostly identified $R$. japonica. This species was found in 11 villages, while $R$. japonica and $R$. × bohemica only in one village (Wiersze). In 102 villages located in the buffer zone we more often encountered $R$. $\times$ bohemica. This species was found in 37 villages, while $R$. japonica was found in 32, and both species were found in 12 villages. $R$. $\times$ bohemica was mainly found in villages near the northern and eastern borders of KNP. On the other hand, $R$. japonica prevailed in locations near the southern and western borders (Fig.1). Numerous sites of this species were identified mainly on the roadsides, particularly in areas were road repairs were carried out, new asphalt surface was laid and roadsides were paved. New sites of $R$. $\times$ bohemica emerging in subsequent years were found near the northeastern border of KNP, particularly abundant in the villages of Adamówek and Łosia Wólka and a huge population near the shopping centre in Łomianki. 
$R$. sachalinensis was detected in villages on the margins of KNP, in its eastern part, both northward (3 sites: Czeczotki, Sowia Wola, Wrzosówka), and southward (one site in Laski, on the forest edge).

Sites of knotweeds usually occupy large areas. They form dense, homogeneous populations. This concerns both the oldest sites of $R$. japonica reported from the area of KNP, and newly formed sites of $R . \times$ bohemica. In places that are managed, e.g. mown or cleared, knotweed plants grow vigorously, and new sites in the vicinity are being formed.

One action aimed at removing knotweed plants from KNP was monitored between 2013 and 2018, on a field in Górki purchased by KNP for the project. In subsequent years $R$. japonica produced new shoots, but each year the regrowth was less vigorous. In 2018 only scarce, small plants of $R$. japonica were observed, regrowing near farm buildings.

\section{Discussion}

The oldest available sources [KOBENDZA, 1930] do not provide information on the sites of Reynoutria species in Kampinoska Forest. The first spontaneously formed sites of $R$. japonica were reported in the 1970s in the buffer zone of Kampinos National Park [NowAK, 1983], in the villages of Babice, Janów, Latchorzew, Leszno, Powązki and Zaborów. Sites from the area of KNP were reported much later, in the 1990s [KIRPLUK, 1996, 1998, 2003, 2009, 2012; FERCHMIN, unpubl.]. The first reports on the presence of $R$. sachalinensis date back to 1985 [Ferchmin, unpubl.]. Sites of $R$. × bohemica were identified in the early $21 \mathrm{st}$ century (authors' own data and data from KNP, unpubl.).

By 2016 there were 129 sites of Reynoutria species reported, both from the area of the surveyed villages and outside them. The most frequently recorded species was $R$. japonica (123 sites, including 61 in KNP and 62 in its buffer zone). Each of the other two taxa have been found on three sites: $R$. sachalinensis (all in the buffer zone), and $R$. $\times$ bohemica (one in the national park and 2 in its buffer zone). However, observations have shown that these data do not reflect the actual distribution of knotweeds in the Kampinoska Forest. This particularly refers to $R$. $\times$ bohemica, which is difficult to distinguish from $R$. japonica [SHEVERA, 2017]. Verification of data revealed that most sites were formed by $R$. japonica (118 sites, of which 64 are within the national park and 54 in the buffer zone), but some of the previously reported sites were in fact occupied by $R$. xbohemica. Overall, $R$. × bohemica has been found on 54 sites (six in KNP and 48 in the buffer zone). Observations carried out in recent years also revealed that $R$. × bohemica emerges in many new locations, quickly occupying considerably large areas. $R$. sachalinensis was found on four sites in the buffer zone of KNP (apart from those previously mentioned in our studies there was a site on the shore of Lake Dziekanowskie).

For $R$. × bohemica we observed that plants escaped from home gardens, where they are cultivated, to ruderal habitats and colonized land near houses and fences, heaps of rubble, cemeteries, etc., where this taxon becomes established and changes its status from an escapee from cultivation (ergasiophyte) to an epecophyte. Next, this knotweed spreads spontaneously to semi-natural habitats (meadows) and natural habitats (forests), and becomes an agriophyte. The behaviour of $R$. japonica is similar - this species, present on numerous sites within KNP, spreads to forest communities located in villages near the national park. Knotweeds are characterised by vigorous growth and strong potential for regeneration [BEERLING et al., 1994; BímOVÁ et al., 2004; BROCK et al., 1995; BRADLEY et al., 2010; SOŁTYSIAK, BREJ, 2012; SuKOPP, STARFINGER, 1995; TOKARSKA-GuZIK et al., 2017]. They quickly colonize new habitats and in a short time can form large patches. By restricting access to light they prevent the growth and germination of native plant species. Allelopathic effects of knotweeds preventing the growth of other plants in their neighbourhood have also been reported [Sharma et al., 2005; MORAVCOVÁ et al., 2011; ViCHOTOVÁ, ŠERÁ, 2008]. 
The activities of KNP, aimed at eradicating the site of $R$. japonica from a field in Górki purchased from a previous owner (as part of the LIFE + "ActiveKPN" project), proved to be effective, although they must be continued. The project ended in 2015, and work aimed at the eradication of knotweed were carried out at the cost of KNP and with the involvement of volunteers. Knotweed plants have been dug out 3-4 times a year. Expenses related to this work are each year earmarked in the budget of the Forest Fund of KNP (oral communication from the employees of KNP). Similar actions aimed at the elimination of sites of $R$. japonica have been carried out in two reserves of KNP - "Kaliszki" and "Zamczysko" (information from the management of KNP). These actions will be effective if work is done systematically, several times a year, until the invasive species is completely eliminated.

The experience of other researchers [TOKARSKA-GUZIK et al., 2012, 2017] shows that without substantial financial resources it is impossible to eradicate these very invasive Reynoutria plants. It is not enough to focus on the elimination of already existing numerous knotweed sites; it is necessary to prevent the formation of new ones. Large-scale campaigns are required to educate citizens, both local residents, who continue to grow knotweeds in their home gardens, and local authorities. The Regulation of the Minister of Environment [Dz. U. 2011 no. 210, item 1260] is not well known to the general public in Poland; this also applies to officials in villages, cities, municipalities and counties. Citizens are also not familiar with other reports commissioned by the General Directorate for Environmental Protection [TOKARSKA-GUZIK et al., 2012, 2017], which discuss in detail problems related to invasive species, including their eradication.

Many of the new sites of Reynoutria in the study area would not have been established if people had known methods of spreading knotweed and relevant services (and residents) had been informed about this. This applies both to the careless disposal of knotweed shoots removed from home gardens and cemeteries, and mowing roadsides as well as other places within the Park and its buffer zone. As a result of such activities, fragments of knotweed plants are introduced to various places, close or distant, or to local green waste dumps, and new populations of these plants are being established. In this way huge patches of $R$. $\times$ bohemica have been formed in recent years near Adamówek, Łosia Wólka, and near the shopping centre in Łomianki. Each new site recorded during subsequent years of field research certainly has anthropogenic origin.

\section{Conclusions}

Home gardens continue to be the major source of knotweed spread in the area of Kampinoska Forest (KNP and its buffer zone). The largest number of sites occupied by Reynoutria species was recorded near urban centres (Warsaw, Łomianki) in the north-eastern and eastern part of KNP, but also along the southern border of KNP, which is associated with the strong urbanization of this area: the concentration of villages, houses and home gardens is much greater here, and a well-developed network of roads and dense development promote the spread of knotweeds.

Although the distribution of knotweeds is largely limited to ruderal habitats, these invasive plants, especially $R$. japonica and $R$. × bohemica, pose a threat to semi-natural and natural biocoenoses at KNP. On some of the sites, mainly those located inside the park, $R$. japonica occupies large areas and forms compact homogeneous populations.

Further efforts aimed at the eradication of sites of Reynoutria species from the area of Kampinos National Park and its close vicinity are necessary. It is advisable to constantly monitor the existing sites of knotweeds and prevent the formation of new ones. Therefore, large-scale campaigns aimed at educating citizens, both local residents and authorities, are required. 


\section{Acknowledgements}

The authors are grateful to Dr. Hanna Werblan-Jakubiec, Head of the Botanic Garden, University of Warsaw, for financial support for field research and translation of the manuscript into English. We also thank $\mathrm{Mr}$ Włodzimierz Winiarski for his help in field research. The authors are grateful to an anonymous reviewer for his valuable comments and suggestions.

\section{References}

ANDRZEJEWSKI R. (ed.) (2004). Kampinoski Park Narodowy. Tom II. Przyroda Kampinoskiego Parku Narodowego. Izabelin: Kampinoski Park Narodowy, 330 p. (in Polish)

BALOGH L. (2008). Japanese, giant and Bohemian knotweed (Fallopia japonica (Houtt.) Ronse Decr., F. sachalinensis (Frdr. Schmidt) Ronse Decr. and F. ×bohemica (Chrtek et Chrtková) J. P. Bailey. In: Botta-Dukát Z., Balogh L. (eds). The most important invasive plants in Hungary. Vácrátót, Hungary: Institute of Ecology and Botany, Hungarian Academy of Sciences: ): 13-33.

BomanowsKa A., Ferchmin M, KIRPLUK I., OtręBA A. (2014). Inwazyjne gatunki roślin we florze Puszczy Kampinoskiej. In: Otręba A., Michalska-Hejduk D. (eds.). Inwazyjne gatunki roślin w Kampinoskim Parku Narodowym i w jego sąsiedztwie. Kampinoski Park Narodowy: 25-35. (in Polish)

BeERling D.J., Bailey J.P., ConOlly A.P. (1994). Fallopia japonica (Houtt.) Ronse Decraene (Reynoutria japonica Houtt.; Polygonum cuspidatum Sieb. Zucc.). Journal of Ecology, 82: 959-979.

Bimová K., MANDÁK B., KASPAROVA I. (2004). How does Reynoutria invasion fit the various theories of invisibility? Journal of Vegetation Science, 15: 495-504.

Bradley B.A., Blumenthal D.M., Wilcove D.S., ZiSKa L.H. (2010). Predicting plant invasions in an era of global change. Trends in Ecology and Evolution, 25: 310-318.

BRAUN M., SChINDLER S., EsSL F. (2016). Distribution and management of invasive alien plant species in protected areas in Central Europe. J. Nat. Conserv., 33: 48-57. doi: 10.1016/j.jnc.2016.07.002

BRock J.H., ChILD L.E., WAAL L.C., WADE M. (1995). The invasive nature of Fallopia japonica is enhanced by vegetative regeneration from stem tissues. In: Pyšek P., Prach K., Rejmánek M., Wade M. (eds.). Plant invasions: general aspects and special problems. Amsterdam: SPB Acad. Publ., 131-139.

BuRda R.I., PASHKEVYCH N.A., BoIKO G.V., FITSAILO T.V. (2015). Alien species of the protect floras of foreststeppe of Ukraine. Kyiv: Naukova Dumka, 117 p.

DAISIE European Invasive Alien Species Gateway (2006). Fallopia japonica. URL: www.europealiens.org/speciesFactsheet.do?speciesId=8137 [22/11/2018].

Dumitraşcu M., Grigorescu I., Kuscicsa G., Doroftei M., NĂstase M., Dragotă C-S. (2014). Invasive terrestrial plant species in the Romanian protected areas. A geographical approach. Rev. Roum. Géogr./Rom. Journ. Geogr., 58 (2): 145-160.

Dz.U. 2011 nr 210, poz. 1260. Rozporządzenie Ministra Środowiska z dnia 9 września 2011 r. w sprawie listy roślin i zwierząt gatunków obcych, które w przypadku uwolnienia do środowiska przyrodniczego mogą zagrozić gatunkom rodzimym lub siedliskom przyrodniczym. (in Polish)

Global Invasive Species Database (2018) Species profile: Polygonum cuspidatum. URL: http://www.iucngisd.org/gisd/speciesname/Polygonum+cuspidatum [22/11/2018].

Hlavati ŠIRKA V., LAKUŠIĆ D., ŠInŽAR-SEKulić J., TONi NikOlić T., JovanoviĆ S. (2013). Reynoutria sachalinensis: a new invasive species to the flora of Serbia and its distribution in SE Europe. Botanica Serbica, 37 (2): 105-112.

Holoborodko K.K., Marenkov O.M., Gorban V.A., Voronkov Y.S. (2016). The problem of assessing the viability of invasive species in the conditions of the steppe zone of Ukraine. Visn. Dnipropetr. Univ. Ser. Biol. Ekol., 24(2): 466-472. doi:10.15421/011663

Jovanović S., Hlavati-ŠIRKa V., LAKUŠIĆ D., Jogan N., NikOlić T., ANASTASIU P., Vladimirov V., ŠInŽARSEKULIĆ J. (2018). Reynoutria niche modelling and protected area prioritization for restoration and protection from invasion: A Southeastern Europe case study. Journal for Nature Conservation, 41: 1-15. doi: 10.1016/j.jnc.2017.10.011

KIRPLUK I. (1996). Structure of ruderal floras in abandoned villages in the Kampinos Forest. In: Terpó A., Mochnacký S. (eds.). II. Anthropization and environment of rural settlements. Flora and vegetation. Proceedings of International Conference. Tarcal-Tokaj,1996: 124-133.

KIRPLUK I. (1998). Anthropophytes of ruderal sites in several villages in the Kampinos Forest. In: Mochnacký S., Terpó A. (eds.). III. Antropization and environment of rural settlements. Flora and vegetation. Proceedings of International Conference. Zemplinska Sirava, 1998: 153-160.

KIRPLUK I. (2003). Antropofity siedlisk ruderalnych wsi puszczańskich Kampinoskiego Parku Narodowego. In: Andrzejewski R. (ed). Kampinoski Park Narodowy. Tom 1. Przyroda Kampinoskiego Parku Narodowego. Kampinoski Park Narodowy, Izabelin: 275-283. (in Polish)

KIRPLUK I. (2009). Gatunki dziczejące z upraw w opuszczanych wsiach Kampinoskiego Parku Narodowego. In: Andrzejewska A., Lubański A. (eds.). Trwałość i efektywność ochrony przyrody w polskich parkach narodowych. Kampinoski Park Narodowy, Izabelin: 237-245. (in Polish) 
KIRPLUK I. (2014). Gatunki z rodzaju rdestowiec Reynoutria spp. In: Otręba A., Michalska-Hejduk D. (eds.). Inwazyjne gatunki roślin w Kampinoskim Parku Narodowym i w jego sąsiedztwie. Kampinoski Park Narodowy, Izabelin: 60-65. (in Polish)

Kobendza R. (1930). Stosunki fitosocjologiczne Puszczy Kampinoskiej. Materiały do flory polskiej. Warszawa: Planta Polonica 2, 201 p. (in Polish)

Monaco A., Genovesi P. (2014). European Guidelines on Protected Areas and Invasive Alien Species. Strasbourg: Council of Europe, Lazio Region, Rome: Regional Parks Agency, 58 p.

Moravcová L., PYŠEK P., JARoŠIK V., ZÁKRAVSKÝ P. (2011). Potential phytotoxic and shading effects of invasive Fallopia (Polygonaceae) taxa on the germination of native dominant species. Neobiota, 9: $31-47$.

OTRĘBA A. (2008). Rozprzestrzenianie się obcych inwazyjnych gatunków roślin jako zagrożenie przyrody Kampinoskiego Parku Narodowego. Dokumentacja Geograficzna, 37: 194-204. (in Polish)

OtręBA A., MichalsKA-HejduK D. (2014). Metody zbioru i opisu danych. In: Otręba A., Michalska-Hejduk D. (eds.). Inwazyjne gatunki roślin w Kampinoskim Parku Narodowym i w jego sąsiedztwie, Kampinoski Park Narodowy, Izabelin: 19-24. (in Polish)

PASHKEVYCH N., BURDA R. (2017). Spread of alien plant species in the habitats of the Ukrainian Forest Steppe. Ekológia (Bratislava), 36 (2): 121-129. doi :10.1515/eko-2017-0011

Protopopova V.V, SheVera M.V. (2014). Ergasiophytes of the Ukrainian flora. Biodiv. Res. Conserv., 35: 3146. doi: 10.2478/biorc-2014-0018

Protopopova V.V., Shevera M.V., Mosyakin S.L. (2006). Deliberate and unintentional introduction of invasive weeds: A case study of the alien flora of Ukraine. Euphytica, 148: 17-33. doi: 10.1007/s10681-006-5938-4

Protopopova V.V., Shevera M.V., Orlov O.O., PAnChenKo S.M. (2015). The transformer species of the Ukrainian Polissya. Biodiv. Res. Conserv., 39: 7-18. doi: 10.1515/biorc-2015-0020

PROTS B. (2013). Invasion success of alien plant species in the Carpathian region of Ukraine. Biological systems (Біологічні системи), 5(1): 116-121.

Sharma G.P., SingH J.S., RAGHUBANSHi A.S. (2005). Plant invasion: emerging trends and future implications. Current Science, 88: 726-734.

SHEVERA M.V. (2017). Reynoutria $\times$ bohemica (Polygonaceae), a potentially invasive species of the Ukrainian flora. Ukr. Bot. J., 74(6): 548-555. (in Ukrainian) doi: 10.15407/ukrbotj74.06.548

SîRBU C., OPREA A. (2008). Two alien species in the spreading process in Romania: Reynoutria $x$ bohemica Chrtek \& Chrtková and Grindelia squarrosa (Pursh) Dunal. Cercetări Agronomice în Moldova, XLI, 2(134): 41-50.

Sîrbu C., Oprea A., SAmuil C., TĂNASE C. (2012). Neophyte Invasion in Moldavia (Eastern Romania) in Different Habitat Types. Folia Geobot., 47: 215-229. doi: 10.1007/s12224-011-9112-y

Sołtysiak J., BREJ T. (2012). Characteristics that make the Fallopia genus (Polygonaceae) highly invasive, Ecological Questions, 16: 23-27, doi: 10.2478/v10090-012-0002-6.

SUDNIK-WÓJCIKOWSKA B., KOŹNIEWSKA B. (1988). Słownik z zakresu synantropizacji szaty roślinnej. Warszawa: WUW, 93 p. (in Polish)

Sukopp H., Starfinger U. (1995). Reynoutria sachalinensis. In: Pyšek P., Prach K., Rejmánek M., Wade M. (eds.). Europe and in the Far East: a comparison of the species ecology in its native and adventive distribution range. In: Plant invasions: general aspects and special problems. Amsterdam: SPB Acad. Publ.: 151-159.

THE Plant List (2013). Version 1.1. URL: http://www.theplantlist.org/ [22/11/2018].

TOKARSKA-GuZiK B., DAJdOK Z., ZAJĄC M., ZAJĄC A., URBisz A., DANIElewiCZ W., HoldyŃsKi CZ. (2012). Rośliny obcego pochodzenia w Polsce ze szczególnym uwzględnieniem gatunków inwazyjnych. Warszawa: Generalna Dyrekcja Ochrony Środowiska, 197 p. (in Polish)

Tokarska-GuziK B., FojciK B., BzdęGA K., Urbisz A., NowAK T., PAsierbińsKi A., DAJdOK Z. (2017). Inwazyjne gatunki z rodzaju rdestowiec Reynoutria spp. w Polsce - biologia, ekologia i metody zwalczania. Katowice: Wydawnictwo Uniwersytetu Śląskiego, 180 p. (in Polish)

VichotovÁ N., ŠERÁ B. (2008). Allopathic properties of knotweed rhizome extracts. Plant Soil and Environment, 54: 301-303.

Рекомендує до друку

Отримано 24.01.2019

Мойсієнко I.I.

Адреси авторів:

I. Кирплюк

Вапшавський університет, Факультет біології,

Ботанічний сад

вул. Уяздовськи 4, 00-478 Варшава
Authors' addresses:

I. Kirpluk

Botanic Garden, Faculty of Biology, University of

Warsaw

Al. Ujazdowskie 4, 00-478 Warsaw 
The spread of Reynoutria species (Polygonaceae) in Kampinos National Park and its vicinity (Central Poland)

Польщза

e-mail: ikirpluk@biol.uw.edu.pl

\section{А. Бомановска}

Кафедра геоботаніки та Екології рослин Факультет біології та захисту довкілля Університет Лоди

Банача 12/16, 90-237, Лоди

Польщза

e-mail: anna.bomanowska@biol.uni.lodz.pl

A. Отреба

Начіональний природний парк Кампінос Тетмаєра 38, 05-080 Ізабелін

Польщча

e-mail:aotreba@kampinoski-pn.gov.pl
Poland

e-mail:ikirpluk@biol.uw.edu.pl

A.Bomanowska

Department of Geobotany and Plant Ecology, Faculty of Biology and Environmental Protection, University of Łódź

Banacha 12/16, 90-237 Łódź

Poland

e-mail: anna.bomanowska@biol.uni.lodz.pl

A.Otręba

Kampinoski National Park

Tetmajera 38, 05-080 Izabelin

Poland

e-mail: aotreba@kampinoski-pn.gov.pl 